\title{
SISTEM BAGI HASIL DALAM SYARIAT ISLAM
}

\author{
Umrotul Khasanah \\ Fakultas Ekonomi UIN Maliki Malang \\ Telepon: 08179642872 \\ Email:umrotul_kh@Yahoo.com
}

\begin{abstract}
Profit sharing system in villages is found in Indonesian society's daily life particularly in fishing, farming and trading sectors. The system which develops within the society and which is close to Islamic economics concept has also been rooted from Indonesian culture. The implementation of profit sharing system that is used by farmers mostly refers to the value of cooperation. The success of implementing those values in aforementioned sectors due to its preaching strategy model using by Walisongo (Nine Ulama) by acculturating the culture. The process of transforming Islam did not cause significant problem within the society that the values became the spirit for particular sectors such as fishing, farming and trading.

Di dalam kehidupan masyarakat Indonesia telah ditemukan sistem bagi hasil di desa-desa khususnya di sektor usaha nelayan, pertanian atau perdagangan. Sistem yang berkembang di kehidupan masyarakat ini yang mendekati konsep ekonomi Islam sebenarnya juga telah lama berakar dari budaya bangsa. Pelaksanaan bagi hasil yang dilaksanakan oleh para petani banyak mengacu pada nilai-nilai dalam bersyarikat. Keberhasilan proses implementasi nilai-nilai Islam ke dalam sistem nelayan, pertanian atau perdagangan ini, karena model strategi dakwah yang dilakukan oleh Wali Songo (Wali Sembilan) yang melakukan akulturasi budaya. Proses transformasi Islam ke dalam sistem nelayan, pertanian atau perdagangan nyaris tampa menimbulkan maslah yang signifikan dalam masyarakat, dan bahkan hampir nilai-nilai tersebut bisa menjadi ruh dlam berbagai kehidupan masyarakat seperti nelayan, pertanian dan perdagangan.
\end{abstract}

\section{Keywords:}

\section{Pendahuluan}

Islam yang mempunyai misi besar menebarkan rahmat kepada semesta alam, ternyata nilai-nilainya sudah banyak diamalkan atau dipraktekkan dalam berbagai dimensi kehidupan rakyat Indonesia. Nilainilai Islam sudah banyak mengalami pribumisasi di seantero nusantara ini. Hal ini tidak mengherankan, karena Islam sudah masuk ke nusantara ini sejak abad pertengahan, terutama di Jawa yang dimotori oleh para ulama yang dikenal dengan sebutan Wali Songo (Wali Sembilan).

Kalangan ulama perintis Islam di tanah masuk di kalangan masyarakat petani. Dalam melakukan misi dakwahnya strategi yang dipakai adalah melalui proses akulturasi. Para Wali itu tidak memberangus total sistem nilai yang sudah mengakar di masyarakat sebelum Is lam masuk, seperti tradisi Hindu dan Budha atau mungkin animisme dan dinamisme. Bahkan bentuk-bentuk tradisi atau budaya yang ada tetap dibiarkan apa adanya, namun sistem nilainya disesuaikan dengan nilai-nilai Islam.

Karena itu tidak mengherankan ternyata dalam masyarakat petani, sistem pertanian yang dilaksanakan secara turun temurun honval harcacuaion danoran Iclam UX/olar-nun 
subtansinya kompatibel dengan nilai-nilai Islam.

Di dalam prakteknya di masyarakat sistem pertanian yang berlaku di kalangan petani, antara daerah satu dengan daerah lainnya berbeda-beda. Meski berbeda-beda bentuknya, tetapi ada titik persamaan dalam pelaksanaannya terutama yang menyangkut hak dan kewajiban antara majikan dan buruh atau antara pemilik modal (sohibul mal) dengan pekerja.

Sesungguhnya apa yang dilakukan Walisongo itu meniru apa yang dilakukan Nabi Muhammad. Sebelum Rasulullah Muhammad menerima wahyu dari Allah untuk diangkat sebagai rasul dan nabi penutup para nabi dan rasul, sebenarnya Nabi Muhammad sudah pernah mempraktekkan model pembiayaan yang sekarang dalam sistem ekonomi Islam dikenal dengan istilah pembiayaan mudharabah. Model pembiayaan seperti ini oleh Nabi Muhammad SAW dianggap sebagai sistem penitipan modal, yaitu tatkala beliau dipercaya membawa sebagian barang dagangan Siti Khadijah r.a. dari Mekkah ke negeri Syam. Barang dagangan itu dijadikan modal usaha oleh Nabi untuk diperdagangkan dan hasilnya dibelikan barang dagangan lainnya untuk dijual lagi di pasar Bushra di Negeri Syam. Setelah beberapa lama, Nabi kembali ke Mekkah membawa hasil usahanya dan dilaporkan kepada Siti Khodijah r.a. Harta yang telah dikembangkan itu tentunya dihitung dan dibandingkan dengan harta semula. Harta semula dikembalikan kepada yang punya, sedang selisihnya dibagi antara yang punya harta (rabbul maal) dengan yang mengelola (mudharib) sesuai dengan kesepakatan semula. (H.M.H. al Hamid al Husaini,dalam Karnaen, 1996: 12).

Wali Songo meniru yang dilakukan Nabi Muhammad, para Wali itu langsung terjun ke masyarakat lewat perdagangan dengan masyarakat petani maupun nelayan. Dalam proses kerjasama baik dalam kaitan dengan perdagangan maupun bekerja di sektor pertanian dan nelayan, para wali mewarnai semua jenis transaksi atau muamalah dengan nilai-nilai Islam. Tradisi dan budaya yang sudah berjalan dibiarkan apa adanya, sehingga perubahan yang terjadi di masyarakat berjalan secara alami atau natural. Para wali tidak melakukan perombakan secara drastis atau dramatik untuk mengubah cara-cara yang tidak dibenarkan oleh syariat Islam. Masyarakat diajak berdialog secara equal, sederajat, sama rata atau sama rasa dalam proses secara alami. Apa yang dilakukan para wali itu sebenarnya adalah proses inovasi dalam tatanan sosial ekonomi masyarakat, namun masyarakat merasakan proses perubahan itu sebagai hasil bersama. Masyarakat tidak pernah merasa bahwa itu hasil pendoktrinan atau pengajaran dari para wali.

Sampai sekarang proses inovasi yang dilakukan oleh para wali ini masih terpelihara di dalam kehidupan masyarakat Indonesia. Dalam praktek sistem pertanian yang ada dalam masyarakat masih kita ditemukan sistem bagi hasil di desa-desa. Sistem model seperti yang berkembang di kehidupan masyarakat ini mendekati konsep ekonomi Islam, tapi nuansa kulturalnya kental sebagai berakar dari budaya bangsa. Contoh yang paling menarik antara lain dalam tata cara pembagian hasil atas garapan tanah pertanian yang sudah lama berlaku di antara mereka seperti sistem paron, bawon atau pertelonan $\mathrm{dsb}$. Dimana sistem-sistem tersebut banyak kesamaannya dengan sistem bagi hasil berdasarkan prinsip Islam.

Para petani juga banyak menggunakan sistem bagi hasil antara pemilik modal (bisa berupa tanah dan atau bibit) dengan para penggarap untuk merawat pertanian tersebut. Dalam pelaksanaan bagi hasil petani tersebut bila mengalami keuntungan maka akan secara damai dibagi begitu juga kalau ada kerugian maka akan dibebankan kepada kedua belah pihak secara proporsional. Bertani merupakan usaha yang penuh resiko, hasil pertaniannya bisa gagal panen sehingga mengalami kerugian yang bisa menghabiskan modal atau jika bernasib baik bisa mendapat keuntungan yang berlebih.

\section{Sumber Ins pirasi Ekonomi Islam}


Dalam sejarah berkembang dan bertumbuhnya Islam, agama hanif ini bisa masuk ke berbagai belahan dunia berlangsung secara damai. Karena Islam itu diikhtiarkan sejak awal sebagai agama yang menebarkan rahmat bagi semesta alam. Rahmat yang ditebarkan itu adalah sifat rahman dan rahim-Nya Allah Swt. Karena itu risalah utama yang akan disebarkan Rasullah Muhammad SAW adalah Islam rahmatan lilalamien ini ( KH A Hasyim Muzadi, 2006). Sesuai dengan firman Allah dalam Surat Anbiya' ayat 107: 'Dan tiadalah Kami mengutus kamu, melainkan untuk (menjadi) rahmat bagi semesta alam (rahmatan lil'alamin)',

Islam sebagai agama yang multikompleks telah memberikan pedoman ke seluruh relung kehidupan umatnya. Demikian juga dalam bidang ekonomi, Islam memberi pedoman-pedoman yang cukup jelas dan tegas. Sumber inspirasi ekonomi di dalam Islam ada empat: (1) al-Qur'an, (2) al-Hadits, (3) al-Ijma', (al-Qiyas). Subtansi nilai yang ditekankan dalam ajaran Islam dalam perekonomian adalah Islam memberikan jalan tengah yang adil; antara dunia dan akhirat, antara rasio dan hati, antara rasio dan norma, antara idealism dan fakta, antara individu dan masyarakat dan lain sebagainya (Veithzal Rivai dan Andi Buchari, 2009).

Firman Allah dalam Al Quran Surat An Nisa' ayat 29.: "Hai orang-orang yang beriman, janganlah kamu saling memakan harta sesamamu dengan jalan yang batil, kecuali dengan jalan perniagaan yang berlaku dengan suka sama suka diantara kamu. Dan janganlah kamu membunuh dirimu: Sesungguhnya Allah adalah Maha Penyayang kepadamu." (QS. 4:29).

Selain surat an-Nisa' tersebut di atas juga disebutkan dalam surat al-Baqarah ayat 275 yaitu: "Orang-orang yang makan (mengambil) riba tidak dapat berdiri melainkan seperti berdirinya orang yang kemasukan syetan lantaran (tekanan) penyakit gila. Keadaan mereka yang demikian itu, adalah disebabkan mereka berkata (berpendapat), sesungguhnya jual beli itu sama dengan riba, padahal Allah telah menghalalkan jual beli dan mengharamkan riba. Orang-orang yang telah sampai kepadanya larangan dari Tuhannya, lalu terus berhenti (dari mengambil riba), maka baginya apa yang telah diambilnya dahulu (sebelum datang larangan); dan urusannya (terserah) kepada Allah. Orang yang mengulangi (mengambil riba) maka orang itu adalah penghuni-penghuni neraka; mereka kekal di dalamnya". (QS. 2:275).

Jika dalam surat al-Baqarah ayat 275 itu Allah menegaskan perbedaan antara perdagangan dengan riba, maka dalam alQuran surat al-Muzammil Allah memberikan penjelasan bahwa manusia harus berusaha mencari karunia Allah. Dengan kata lain, meski rizki itu Allah sudah menyediakan, namun untuk mendapatkannnya perlu suatu upaya, sebagaimana dalam Firman-Nya:

".... Dia mengetahui bahwa akan ada di antara kamu orang-orang yang sakit, dan yang lain berjalan di bumi mencari sebagian karunia Allah, dan yang lain berperang di jalan Allah, maka bacalah yang mudah (bagimu) dari al-Quran dan laksanakanlah shalat, tunaikan zakat dan berikanlah pinjaman kepada Allah pinjaman yang baik...' Q.S. al-Muzammil ayat 20).

Dalam pengertian fiqih Islam, mereka yang melakukan perjalanan niaga (dharb) mencari sebagian karunia Allah adalah para pengusaha (entrepreneur) yang bertindak sebagai mudharib yang terikat dalam perjanjian mudharabah (qirad) dengan sistem bagi hasil. Dalam pengertian fikih Islam juga disebutkan bahwa syirkah berarti persekutuan atau perkongsian antara dua orang atau lebih untuk melakukan usaha bersama dengan tujuan memperoleh keuntungan. Keuntungan atau kerugian dibagikan menurut perbandingan banyaknya modal atau dibagi menurut perjanjian di antara mereka. Perintah lainnya yang penting untuk memeratakan kesempatan berusaha secara luas ialah yang terdapat dalam al-Qur'an surat al-Hasyr ayat 7. "Apa saja harta rampasan (fai-i) yang diberikan Allah kepada Rasul-Nya yang berasal dari penduduk kota-kota maka adalah untuk Allah, Rasul, kerabat Rasul, anak-anak 
yatim, orang-orang miskin dan orang-orang yang dalam perjalanan, supaya harta itu jangan hanya beredar diantara orang-orang kaya saja diantara kamu. Apa yang diberikan Rasul kepadamu maka terimalah dia. Dan apa yang dilarangnya bagimu maka tinggalkanlah; dan bertaqwalah kepada Allah. Sesungguhnya Allah sangat keras hukumnya." (QS 59:7).

\section{Konsep Maslahah dalam Ekonomi Islam}

Syariah Islam menginginkan manusia mencapai dan memelihara kesejahteraannya. Imam Syatibi menggunakan istilah 'maslahah', yang maknanya lebih luas dari sekedar utility atau kepuasan dalam terminologi ekonomi konvensional. Maslahah merupakan tujuan hukum syara' yang paling utama.

Menurut Imam Syatibi, maslahah adalah sifat atau kemampuan barang dan jasa yang mendukung elemen-elemen dan tujuan dasar dari kehidupan manusia di muka bumi ini. Ada lima elemen dasar menurut Imam Syatibi yaitu: kehidupan atau jiwa (al nafs), properti atau harta benda (al maal), keyakinan ( $a l$ din), intelektual ( $a l a q l$ ), dan keluarga atau keturunan ( al nasl). Semua barang dan jasa yang mendukung tercapainya dan terpeliharanya kelima elemen tersebut untuk memenuhi kebutuhan setiap individu, itulah yang disebut maslahah (As-Syatibi dalam Kitab al-Muwafakat Fii Ushuli asSyariah). Tujuan dari semua itu bukan hanya untuk kepentingan duniawi saja, tetapi juga untuk kesejahteraan akhirat. Dan semua aktivitas tersebut yang memiliki maslahah bagi umat manusia itu disebut 'needs' atau kebutuhan. Dan semua kebutuhan itu harus terpenuhi..

Untuk mencukupi kebutuhan dan bukan memenuhi kepuasan/keinginan adalah tujuan dari aktivitas ekonomi Islami, dan usaha pencapaian tujuan itu adalah salah satu kewajiban dalam beragama. Adapun sifatsifat maslahah adalah sebagai berikut:

1. Maslahah bersifat subjektif dalam arti bahwa setiap individu menjadi hakim bagi masing-masing dalam menentukan apakah suatu perbuatan merupakan suatu maslahah atau bukan bagi dirinya.

2. Maslahah orang per orang akan konsisten dengan maslahah orang banyak.

3. Konsep maslahah mendasari semua aktifitas ekonomi dalam masyarakat, baik itu produksi, konsumsi, maupun dalam pertukaran dan distribusi. (Mustafa E.Nasution dkk., 2006: 62)

Berdasarkan elemen tersebut, maka maslahah bisa dikategorikan menjadi dua bagian yaitu pertama, maslahah yang menyangkut kehidupan dunia dan akhirat. Kedua, maslahah yang menyangkut kehidupan akhirat. Sehingga dalam diri seorang Islam mempunyai dua pilihan yaitu a). Berapa bagian pendapatannya yang akan dialokasikan untuk maslahah jenis pertama dan berapa untuk maslahah jenis kedua. b) Bagaimana memilih di dalam maslahah jenis pertama: berapa bagian pendapatannya yang akan dialokasikan untuk memenuhi kebutuhan kehidupan dunia (dalam rangka mencapai 'kepuasan' di akhirat) dan berapa bagian untuk kebutuhan akhirat. (Mustafa E.Nasution dkk., 2006: 64).

Di dalam Islam juga diajarkan bahwa sebaik-baik orang adalah orang yang banyak manfaatnya bagi orang lain atau masyarakat. Fungsi beribadah dalam arti yang luas ini tidak akan bisa tercapai jika seseorang tidak bekerja atau berusaha. Dengan demikian bekerja dan berusaha itu adalah menempati posisi yang penting dalam ekonomi Islam.

Pada prinsipnya Islam juga lebih menekankan berproduksi demi untuk memenuhi kebutuhan orang banyak, bukan hanya sekedar memenuhi segelintir orang yang memiliki uang sehingga memiliki daya beli yang lebih baik. Karena itu bagi Islam, produksi yang surplus dan berkembang baik secara kuantitatif maupun kualitatif tidak dengan sendirinya mengidentifikasikan kesejahteraan bagi masyarakat. Apalah artinya produk yang menggunung jika hanya bisa didistribusikan untuk segelintir orang yang memiliki uang banyak. Hal ini sesuai dengan firman Allah dalam al-Quran surat al Baqarah ayat 22. Dalam ayat tersebut 
dijelaskan tentang bumi dan segala isinya untuk manusia dan untuk diolah bagi kemaslahatan bersama bagi seluruh umat manusia.

Islam menganggap sikap produktif sebagai perilaku yang saleh, karena merupakan salah satu aspek manusia sebagai kholifah di muka bumi ini. Orang yang semakin banyak terlibat dalam kegiatankegiatan ekonomi akan bisa semakin baik, selama kehidupannya tetap menjaga keseimbangan dunia dan akhiratnya. Kesalehan bukan fungsi positif dari ketidakproduktifan ekonomi. Semakin saleh kehidupan seseorang, justru seharusnya dia semak in produktif, sesuai firman Allah:

'Barangsiapa mengerjakan kebajikan, baik laki-laki maupun perempuan dalam keadaan beriman, maka pasti akan Kami berikan kepadanya kehidupan yang baik dan akan Kami beri balasan dengan pahala yang lebih baik dari apa yang telah mereka kerjakan,' (Q.S. An-Nahl ayat 97).

Dengan demikian, Islam tetap menaruh apresiasi yang besar terhadap perilaku produktif. Tentu saja, perilaku produktif itu dalam koridor menjaga keseimbangan antara untuk kehidupan dunia dan akhirat.

\section{Konsep Moral Islam dalam Proses Bagi Hasil}

Secara umum, prinsip nilai Islam dalam kehidupan aktivitas ekonomi masyarakat, khususnya dalam konsep pembiayaan sistem bagi hasil, harus mengedepankan nilai-nilai yang Islami, yaitu:

A. Mencari ridho Allah. Hal ini amat penting karena segala perbuatan, tindakan manusia, bukan hanya untuk kepentingan dunia saja melainkan juga untuk tujuan akhirat yang tujuan akhirnya untuk mencari ridho Allah SWT. Karena itu, bagi seorang muslim setiap melakukan aktivitas baik ketika bertani, berdagang dan di dunia profesi apapun harus dikerangkakan dalam knteks beribadah kepada Allah SWT. Semakin bertambah kebaikan amalnya, semakin bertambah pula taqwa dan taqorrub-nya kepada Allah SWT. Kita niatkan kegiatan yang dilakukan hanyalah mencari ridho Allah sesuai dengan firman Allah dalam surat Al-Mulk ayat 15 .

B. Iman yang kuat. Iman kepada Allah SWT adalah sebagai pengawas internal atau hati nurani yang tumbuh dari hati seorang muslim yang bisa menjadi pengawas bagi dirinya. Dengan iman yang kokoh dalam nuraninya merupakan pengawasnya yang pertama dalam segala kegiatan yang dilakukan. Dengan adanya kesadaran tersebut akan menjadi pengawas dalam kegiatannya sehingga apa yang dilakukan adalah hal-hal yang halal atau baik, dan menjauhkan dari yang haram dan buruk.

C. Perwakilan harta Allah SWT. Dalam Islam terdapat sistem nilai kepemilikan, yaitu bahwa sesungguhnya semua kepemilikan manusia sejatinya kepemilikan tersebut merupakan "wakil" dari yang Maha Memiliki yaitu Allah SWT. Dengan demikian, seorang muslim yang mempunyai harta, maka harta tersebut sebenarnya adalah harta Allah SWT. Dia-lah yang menciptakan dan memilikinya, sedangkan manusia adalah wakil dan pemegang amanah terhadap harta tersebut. Konsep inilah yang sering dilupakan manusia khususnya pemilik modal (stoke holder), sehingga rizki yang mereka peroleh enggan untuk dikurangi, demi membelanjakan atau men-tasyarruf-kan sebagian dari harta tersebut di jalan Allah, yaitu menunaikan kemaslahatan umat, seperti membayar zakat, infaq dan sadaqah.

D. Akhlaqul Karimah. Akhlaq memegang peranan utama dalam kehidupan Islam. Begitu pentingnya akhlaq, sehingga Allah SWT menyatakan bahwa terutusnya Nabi Muhammad SAW hanya untuk 
menyempurnakan akhlaq, sesuai sabda Nabi: "Sesungguhnya tiadalah aku diutus, melainkan hanya untuk menyempurnakan akhlaq," (HR Muslim). Dalam kehidupan ekonomi, Islam berpandangan bahwa dalam melakukan aktivitas bisnis harus menjunjung tinggi etika bisnis dan ajaran moral Islam. Seorang non muslim-pun mengakui kehebatan Islam dengan sistem akhlaqnya, seperti yang diakui penulis Perancis, Jack Aster dalam bukunya "Is lam dan Perkembangan Ekonomi” berkata: "Islam adalah sebuah sistem hidup yang aplikatif dan secara bersamaan mengandung nilai-nilai akhlaq yang tinggi. Kedua hal ini berkaitan erat, tidak pernah terpisah satu dengan yang lainnya'. Dengan kata lain, sistem etika bisnis Islam kurang kompatibel dengan sistem ekonomi kapitalis. Lebih pasnya, bisa dikatakan etika bisnis Islam adalah sistem kapitalis plus, yaitu plus akhlaq. Karena sumber inspirasi sistem nilai ekonomi Islam mengambil kekuatan dari wahyu alQuran, yaitu sistem ekonomi yang berakhlaq. Akhlaq ini mampu memberikan makna baru terhadap konsep nilai, dan mampu mengisi kekosongan pikiran yang nyaris muncul akibat alat industrialisasi, (Yusuf Qardhawi, 2001: 61).

E. Tidak dzalim dan harus adil. Dalam pelaksanaan bersyarikat atau proses bagi hasil tidak boleh berbuat dzalim dan harus berbuat adil. Pemilik modal tidak boleh sewenang-wenang dengan membuat keputusan sendiri yang hanya menguntungkan pada dirinya saja. Sedangkan kepentingan lainnya seperti pegawai, masyarakat sekitarnya dan masyarakat pada umumnya diabaikan. Seorang muslim yang baik tidak akan melakukan hal yang dilarang dalam agama yaitu berbuat dzalim. Karena dengan berkeyakinan bahwa bila dia berbuat dzalim maka Allah akan membalasnya. Jadi dalam sistem ekonomi Islam harus dihindari perbuatan dzalim tersebut.

F. Tidak ada unsur riba. Larangan Allah terhadap pengambilan riba adalah sudah jelas dan pasti yang terdapat dalam surat al-Baqarah ayat 275. Riba adalah pertambahan atau pertumbuhan atau perbuatan mengambil sejumlah uang yang berasal dari seorang yang berutang secara berlebihan. Riba jaman jahiliyah adalah bila pada suatu ketika seorang memberikan pinjaman untuk suatu jangka waktu tertentu dan apabila periode itu telah habis, si pemberi utang akan menarik lebih jika tidak tepat waktu dalam pengembaliannya (MA.Manan, 1992). Di satu sisi, sistem ekonomi sekarang tidak hanya memberikan pengembalian lebih bila tidak tepat waktu membayarnya, bahkan sudah ditentukan sejak awal transaksi berapa kelebihan yang harus dibayarkan. Pihak lain, sistem ekonomi Islam menghendaki pemisahan secara tegas antara pemasukan atau pengeluaran yang berbau riba dan yang bukan. Maka, yang harus diperbuat kita sekarang adalah melakukan perbaikan sistem ekonomi yang ada menuju pada pengamalan syariat Islam yang tepat dan benar.

G. Tidak ada unsur penipuan dan bersikap jujur. Realisasi sistem bagi hasil dalam laporan bersyarikat/usaha bisnis, sistem ekonomi Islam tidak diperbolehkan ada unsur penipuan untuk kepentingan individu atau kelompok tertentu, sehingga dapat merugikan lainnya. Setiap pencatatan haruslah sesuai dengan fakta sebenarnya. Contohnya bersikap jujur tentang harga yang sebenarnya dan tidak menyembunyikan sesuatupun darinya atau jumlah dari hasil yang akan dibagikan harus dilaporkan dengan jujur. 
H. Keseimbangan. Ruh sistem ekonomi Islam, yaitu terdapat nilai keseimbangan yang adil dalam semua proses transaksi ekonomi. Tidak boleh ada unsur kedzaliman yang menganiaya masyarakat ---terutama masyarakat lemah--- seperti yang terdapat dalam ekonomi kapitalis. Tidak boleh juga menganiaya hak-hak dan kebebasan individu, seperti yang dilakukan oleh komunis terutama Marxisme. Prinsip keseimbangan ini adalah tidak menyia-nyiakan dan tidak berlebih-lebihan, tidak melampaui batas dan tidak pula merugikan, sebagaimana firman Allah SWT dalam surat ar-Rahman ayat 79.

I. Menghindari fitnah. Dalam ekonomi Islam seharusnya menghindari hal-hal yang berakibat menimbulkan fitnah. Harta itu bukan sesuatu yang buruk dan bukan pula siksaan. Ia juga bukan ukuran bagi ketinggian derajat pemiliknya, atau tanda akan keutamaan dan kesalehannya. Akan tetapi, ia merupakan nikmat dari Allah SWT. Yang dengannya ia akan menguji kepada pemiliknya, apakah bersyukur ataukah kufur. Karena itu Allah menyebut harta dengan "fitnah" yaitu ujian dan cobaan yang terdapat dalam al-Quran surat al-Anfaal ayat 28.

J. Kemaslahatan. Apa yang dilakukan manusia khususnya pemilik modal harus mempertimbangkan untuk kemaslahatan hidup manusia bukan merusaknya. Islam mengharamkan kepada pemilik harta menggunakan kepemilikannya untuk berbuat kerusakan di muka bumi atau melakukan sesuatu yang membahayakan manusia, Rasulullah SAW bersabda: "Tidak boleh ada bahaya dan tidak boleh pula membahayakan (orang lain)" (HR. Ahmad dan Ibnu Majah dari Ibnu Abbas, dan Ibnu Majah dari Ubadah bin Shamit, sebagaimana terdapat dalam Shahih-al-Jami' ash-Shaghir: 7517).

K. Meyakini adanya konsep barakah. Barakah adalah satu karunia yang tidak bisa dilihat (invisible blessing). Ini adalah sebuah pertumbuhan yang tidak bisa dikalkulasi dengan hitungan dolar dan mata uang apa saja. AlAsfahani mendefinisikan barakah adalah Rahmat Allah yang terjadi dengan cara yang tidak bisa dilihat, tidak bisa dikalkulasi dan juga tidak bisa digambarkan (Abu al Qasim, 1967: 44). Konsep tentang barakah ini meliputi semua spektrum perilaku manusia. Ada tidaknya sebuah barakah amat tergantung pada benar tidaknya sebuah perilaku dan tindakan seseorang. Dalam al-Quran Allah berfirman: "'Allah memusnahkan riba dan menyuburkan sedekah. Allah tidak menyukai setiap orang yang tetap dalam kekafiran dan bergelimang dosa," (Q.S. al-Baqarah ayat 276). Ayat tersebut dapat diambil makna bahwa harta akan berkurang karena riba dan akan bertambah berkat sedekah, yang tampak di luaran sebagai sesuatu yang paradoksal (sebab riba di dunia adalah semakin berkembangnya harta, sedangkan sedekah tampaknya mengurangi harta). Teori ini kelihatannya adalah teori yang aneh namun jika ini dipraktekkan, maka akan tampak bukti kebenarannya dan validitasnya. Orang yang beriman diperintahkan untuk meningkatkan dan menambah harta mereka lewat jalan sedekah (yakni memberikan harta kepada mereka yang miskin dan menghajatkan dengan semata-mata mengharapkan ridho Allah dan tidak mengharapkan apa-apa dari para penerima. Rasulullah bersabda: "Tidak akan berkurang harta karena sedekah," (HR Muslim). Sedekah akan memberikan efek positif pada harta kekayaan. Bagi seorang muslim yang memiliki kepercayaan yang kuat 
akan konsep barakah., berarti ia memiliki sebuah aset yang besar. Kepercayaan ini akan mendorong dirinya untuk berbuat dan berperilaku baik, meskipun tampaknya tidak menguntungkan (Mustaq Ahmad, 2001: 64). Dalam sistem bagi hasil perlu konsep barakah, sebab dengan adanya konsep tersebut maka hal-hal yang dilakukan tidak hanya hal-hal yang bersifat materi saja, tetapi juga yang non materi. Dengan melaksanakan sedekah, tidak berarti pengurangan pada sisi laba atau keuntungan, tetapi ada sesuatu barokah yang Allah janjikan di balik itu. Dengan kata lain, memberi sedekah bukan mengurangi modal yang ada, tetapi bahkan Allah akan menambahkan rizki kita.

\section{Bagi Hasil dapat Meningkatkan Kesejahte raan}

Tidak sedikit ajaran Islam yang secara implisit maupun eksplisit menyatakan bahwa Islam mendorong peningkatan produktivitas masyarakat dan menekan kemiskinan (Yusuf Qardawi, 1995: 37). Seiring dengan itu, Islam mencegah pemborosan dan melindungi kekayaan dan sumber daya masyarakat dengan menghindari segala jenis tindakan mubazir, termasuk perjudian dan mengharuskan pemeluknya agar berusaha dan bekerja untuk mencapai kehidupan yang sejahtera.

Bagi hasil adalah salah satu skim yang ada dalam ekonomi Islam serta merupakan salah satu komponen dalam sistem kesejahteraan Islam. Apabila pelaksanaan proses bagi hasil ini benar-benar dilaksanakan sebagaimana dicontohkan oleh Nabi SAW, niscaya akan meningkatkan kesejahteraan masyarakat, mengurangi pengangguran, dan sekaligus mengurangi jumlah kaum fakir-miskin serta terciptanya keadilan dalam distribusi pendapatan. Apabila kesejahteraan mas yarakat meningkat, sudah jelas kaum miskin secara berangsurangsur akan bisa dientaskan.
Sistem kesejahteraan Islam dengan segala sisinya merupakan kesatuan yang utuh. Sektor ekonomi Islam berkait dengan sektor filsafat. Kaitan kedua sektor ini bisa merangsang individu untuk selalu giat bekerja dan menciptakan inovasi dan langkah terobosan. Bagi hasil pun berkait dengan filsafat. Kaitan itu menghasilkan perlindungan atas kepemilikan hak milik perorangan namun sekaligus pencegahan terhadap kerakusan dan keserakahan serta terciptanya keadilan. Islam pun membukakan jalan bagi setiap pribadi untuk berprestasi dan berkompetisi secara wajar (Yusuf Qardawi, 1995: 37).

Bila mendapatkan bagi hasil yang lebih, maka sebaiknya umat Islam tidak lupa dengan kewajibannya yaitu membayar zakat. Lebih lanjut Qardhawi menjelaskan, bahwa menurut prinsip Islam, kekayaan harus menyandang sistem kesejahteraan yang bertumpu pada zakat sebagai bentuk syukur atas segala yang dianugerahkan Tuhan. Selain sebagai sarana untuk menyucikan jiwa dan harta, zakat juga merupakan tip bagi jaminan perlindungan, pengembangan dan pengaturan peredaran serta distribusi kekayaan. Cara memanfaatkannya didasarkan pada fungsi sosialnya bagi kepentingan masyarakat yang menyentuh kalangan miskin maupun kaya. Islam melarang pemakaian harta benda semata-mata untuk kemewahan dan pamer. Lagi pula, dalam rangka pengembangan investasi, Islam melarang monopoli yang merupakan pilar utama berdirinya sistem kapitalisme dan eksploitasisme. Islam mengharuskan diterapkannya prinsip keadilan, termasuk juga dalam hal pemerataan kesejahteraan (Faruq An Nabahan, 2000: 68).

Dalam pandangan ajaran Islam, di dalam harta orang kaya terdapat harta orang miskin dan penekun agama (sabilillah) yang harus dikeluarkan dalam bentuk zakat, infak, sedekah, dan sebagainya. Perintah menafkahkan harta guna membantu mereka yang kurang beruntung dan tekun menegakkan syiar agama, merupakan ibadah yang berdimensi prinsip keadilan sosial dan pemerataan kesejahteraan. Monzer Kahf 
menyatakan bahwa zakat dan sistem waris (faraid) mengarah pada distribusi harta yang egaliter (orang yang tak mau mengeluarkan zakat boleh dikenai tindakan represifkoersif). Sebagai akibat dari penunaian zakat, harta kekayaan selalu beredar di tengah masyarakat. Upaya untuk memperoleh kemajuan ekonomi secara merata bukan kejahatan dalam pandangan Islam. Bahkan ia menjadi sebuah kebaikan bila bisa diseimbangkan dan diniatkan untuk mendapatkan kebaikan (Monzer Kahf, 1995: 19-20).

Berdasarkan pengertian tersebut, visi zakat dirumuskan sebagai mengubah mustahiq menjadi muzakki. Visi ini menggariskan perolehan zakat yang harus bisa mengurangi jumlah kaum fakir-miskin. Jika zakat sudah dibayarkan kepada fakirmiskin dan mereka tetap menjadi fakirmiskin, berarti visi tersebut tak dijalankan. Oleh karena itu, dalam pengelolaan zakat diperlukan adanya amil. Adalah tanggungjawab amil untuk mengurangi angka kemiskinan. Atas dasar itu, dalam mengelola zakat, amil seharusnya menentukan targettarget kerja dengan tujuan mengurangi jumlah mustahiq. Muzakki dilarang menunda-nunda pengeluaran zakat sampai lewat setahun, begitu juga badan amil zakat dilarang mengendapkan dana zakat yang telah dihimpun tanpa didistribusikan atau memanfaatkannya untuk tujuan yang bisa menzalimi asnaf lain. Itu termasuk penyelewengan visi dan misi zakat (Didin Hafidudin, 2002).

Para pakar ekonomi Islam pun sependapat, bahwa zakat merupakan instrumen pengamanan sosial (social security). Itu berarti pengelolaan zakat harus dapat menetralisasi keresahan sosial dan mengentaskan kemiskinan. Mereka pun lebih jauh sependapat, bahwa sampai saat ini masih banyak lembaga amil zakat tradisional yang hanya menghimpun dan menyalurkan zakat. Cara pandang dan program kerja amil tradisional yang sedemikian ini perlu diubah dengan meningkatkan kemampuan dan peran mereka sebagai agen pengentas kemiskinan.
Dengan demikian, dapat dikatakan bahwa realisasi kesejahteraan dalam Islam dan aktualisasi sistem bagi hasil dalam aktivitas ekonomi, harus menggunakan prinsip-prinsip Islam. Konsepsi ini bermuara pada terciptanya keadilan dan kesejahteraan dalam aktivitas ekonomi masyarakat.

\section{Pembiayaan dan Prinsip-prinsip Ekonomi Islam}

Bagi untung rugi merupakan salah satu konsep ekonomi Islam. Bagi untung rugi juga bisa disebut dengan konsep bagi hasil atau profit sharing. Profit sharing dalam kamus ekonomi diartikan sebagai laba. Secara definitif profit sharing diartikan: "distribusi beberapa bagian dari laba pada para pegawai dari suatu perusahaan". Lebih lanjut dikatakan bahwa hal ini dapat berbentuk suatu bonus uang tunai tahunan yang didasarkan pada laba yang diperoleh pada tahun-tahun sebelumnya, atau berbentuk pada pembayaran mingguan atau bulanan.

Keuntungan yang dibagihasilkan harus dibagi secara proporsional antara shohibul maal dengan mudharib. Dengan demikian, semua pengeluaran rutin yang berkaitan dengan bisnis mudharabah, bukan untuk kepentingan pribadi mudharib, dapat dimasukkan ke dalam biaya operasional. Keuntungan bersih harus dibagi antara sahibul maal dan mudharib sesuai dengan proporsi yang disepakati sebelumnya dan secara eksplisit disebutkan dalam perjanjian awal. Tidak ada pembagian laba sampai semua kerugian telah ditutup dan equity (modal) shahibul maal telah dibayar kembali. Jika ada pembagian keuntungan sebelum habis masa perjanjian akan dianggap sebagai pembagian keuntungan dimuka. (Muhammad, 2005: 19).

Inti dari pelaksanaan investasi yang menggunakan bagi hasil pada dasarnya adalah terletak pada kerjasama yang baik antara shahibul maal dengan mudharib. Kerjasama atau partnership merupakan karakter dalam masyarakat ekonomi Is lam. Kerjasama ekonomi harus dilakukan dalam semua lini kegiatan ekonomi, yaitu: produksi, distribusi barang maupun jasa. Salah satu 
bentuk kerjasama dalam bisnis atau ekonomi Islam adalah qirad atau mudharabah. Qirad atau mudharabah adalah kerjasama antara pemilik modal atau pemilik dana dengan pengusaha pemilik keahlian atau ketrampilan atau tenaga dalam pelaksanaan unit-unit ekonomi atau proyek usaha. Melalui qirad atau mudharabah kedua belah pihak yang bermitra tidak akan mendapatkan bunga, tetapi mendapatkan bagi hasil atau profit dan loss sharing dari proyek ekonomi yang disepakati bersama.

Dengan melalui bagi hasil maka akan tercipta suatu tatanan ekonomi yang lebih merata. Implikasi dari kerjasama ekonomi adalah aspek sosial politik dalam pengambilan keputusan yang dilakukan secara musyawarah untuk memperjuangkan kepentingan bersama di bidang ekonomi, kepentingan negara dan kesejahteraan rakyat. Sistem ekonomi berdasarkan bagi hasil akan juga menjamin alokasi sumber ekonomi yang lebih baik dan terjadinya distribusi pendapatan yang lebih sesuai. Konsep bagi hasil dirancang untuk terbinanya kebersamaan atau kemitraan dalam menanggung resiko usaha dan menikmati hasil usaha antara pemilik dana (shahibul maal) dan pengelola usaha ( mudharib). Ada tujuh macam pembiayaan yang berkembang di lembaga keuangan dengan skim syariah, yaitu:

\section{Macam Pe mbiayaan Dengan Skim Syariah}

\begin{tabular}{|c|l|l|}
\hline No. & Macam Pembiayaan & \multicolumn{1}{c|}{ Arti } \\
\hline 1. & Mudharabah & $\begin{array}{l}\text { Pembiayaan seluruh kebutuhan modal pada suatu } \\
\text { usaha untuk jangka waktu terbatas sesuai kesepakatan. }\end{array}$ \\
\hline 2. & Musyarakah & $\begin{array}{l}\text { Pembiayaan sebagian kebutuhan modal pada suatu } \\
\text { usaha untuk jangka waktu terbatas sesuai kesepakatan. }\end{array}$ \\
\hline 3. & Murabahah & $\begin{array}{l}\text { Pembiayaan berupa talangan dana yang dibutuhkan } \\
\text { untuk membeli suatu produk dengan kewajiban } \\
\text { mengembalikan talangan dana tersebut seluruhnya pada } \\
\text { waktu jatuh tempo. }\end{array}$ \\
\hline 4. & Bai' bitsaman ajil & $\begin{array}{l}\text { Pembiayaan berupa talangan dana yang dibutuhkan } \\
\text { untuk membeli suatu produk dengan kewajiban } \\
\text { mengembalikan talangan dana tersebut secara mencicil } \\
\text { sampai lunas dalam jangka waktu tertentu sesuai } \\
\text { dengan kesepakatan. }\end{array}$ \\
\hline 5. & Ijarah & $\begin{array}{l}\text { Pembiayaan berupa talangan dana yang dibutuhkan } \\
\text { untuk memiliki suatu produk dengan kewajiban } \\
\text { menyewa barang tersebut sampai jangka waktu tertentu } \\
\text { sesuaidengan kesepakatan. }\end{array}$ \\
\hline 6. & ar Rahn & $\begin{array}{l}\text { pembiayaan yang berupa pinjaman dana tunai dengan } \\
\text { jaminan barang bergerak yang relatif nilainya tetap } \\
\text { seperti perhiasan emas, perak, intan, berlian, batu } \\
\text { mulia, mobil, sertifikat rumah dll. Untuk jangka waktu } \\
\text { tertentu sesuai dengan kesepakatan. }\end{array}$ \\
\hline 7. & Qardhul Hasan & $\begin{array}{l}\text { Pembiayaan berupa pinjaman tanpa dibebani biaya } \\
\text { apapun bagi kaum dhuafa yang ingin berusaha kecil- } \\
\text { kecilan }\end{array}$ \\
\hline
\end{tabular}

Sumber: Karnaen, 1996, hlm. 15.

\section{Prinsip-prinsip Pembiayaan}

No. Prinsip 


\begin{tabular}{|c|l|}
\hline 1. & $\begin{array}{l}\text { Sistem al Mudharabah mempertemukan antara pemilik modal (rabbul maal) tetapi tidak } \\
\text { ahli berusaha dengan mereka yang ahli berusaha (mudharib) tetapi tidak punya modal. }\end{array}$ \\
\hline 2. & $\begin{array}{l}\text { Sistem al Mudharabah yang didasari atas kepercayaan (trust financing) dimana } \\
\text { mudharib harus lah orang yang cukup dikenal akhlaknya dan dapat dipercaya. }\end{array}$ \\
\hline 3. & $\begin{array}{l}\text { Rabbul maal menyediakan 100\% modal usaha, umumnya sudah dalam bentuk barang } \\
\text { yang siap diperdagangkan atau siap dipakai sebagai modal usaha oleh mud harib, tanpa } \\
\text { turut campur rabbul maal baik dalam manajemen maupun operasional. }\end{array}$ \\
\hline 4. & $\begin{array}{l}\text { Sistem al Mudharabah mempunyai batas waktu, dimana pada ba tas waktu yang telah } \\
\text { ditetapkan modal awal dikembalikan dan diadakan perhitungan beberapa hasil yang } \\
\text { diperoleh dari pengelolaan modal awal tadi. }\end{array}$ \\
\hline 5. & $\begin{array}{l}\text { Porsi pembagian hasil usaha masing-masing disepakati sebelum diberikan pinjaman } \\
\text { modal al mudharabah. Apabila terjadi rugi, maka rabbul maal akan menanggung } \\
\text { kerugian modal sedang mudharib menanggung kerugian waktu dan tenaga serta } \\
\text { pikirannya. }\end{array}$ \\
\hline 6. & $\begin{array}{l}\text { Pada sistem al Mudharabah, rabbul maal dapat menerapkan syarat-syarat untuk } \\
\text { mengamankan modal yang dipinjamkan kepada mudharib. }\end{array}$ \\
\hline 7. & $\begin{array}{l}\text { Sistem al Mudharabah hanya dapat diterapkan pada usaha-usaha yang relatif cepat } \\
\text { menghasilkan. }\end{array}$ \\
\hline
\end{tabular}

Penerapan prinsip-prinsip tersebut pada kelembagaan ekonomi Islam menghasilkan produk-produk pembiayaan yang akan sangat membantu masyarakat terutama dalam rangka upaya mengentaskan kemiskinan di perkotaan dan pedesaan.

\section{Pribumisasi Syariat Islam}

Gagasan pribumisasi Islam dalam konteks lokal, menjadi wacana serius pada dekade tahun 90-an, pencetusnya adalah $\mathrm{KH}$ Abdurrahman Wahid atau Gus Dur. Menurut Gus Dur, pentingya pribumisasi Islam agar Muslim Indonesia dapat tetap mempertahankan identitas ke-indonesiaannya yang khas. Tetapi pada saat yang sama dapat mengejawantahkan nilai-nilai Islam dalam praktik kehidupannya. Karena menjadi seorang Muslim Indonesia tak harus menjadi Arab. Kekhasan potret Islam Indonesia bisa jadi memberikan inspirasi bagi wilayah lain dalam konteks global (Abdurrahman Wahid, Islam Kosmopolitan, 2007).

Dalam kenyataannya Islam Indonesia memang sudah mengalami pribumisasi, itu tidak lain karena peran yang dilakukan oleh para peletak dasar Islam di bumi Nusantara yang dikenal dengan Wali Songo itu. Para ulama yang yang memperkenalkan Islam di bumi Nusantara itu lewat jalur perdagangan dan dengan corak Islam yang sufistik, bukan lewat jalur ekspansi (Andree Feillard, 2008).

Aktualisasi sistem bagi hasil yang merupakan derivasi dari sistem muamala atau transaksi dalam bidang perdagangan, pertanian dan masyarakat nelayan sudah menjadi tradisi yang baku. Sistem bagi hasil ini terlembagakan di masyarakat nelayan, petani dan pedagang lewat pewarisan nilainilai dari generasi ulama perintis ke generasi berikut hingga menjadi nilai baku di masyarakat. Walisongo yang tersebar di daerah pesisir utara pulau Jawa hingga masuk ke pedalaman menyalurkan syariah Islam dalam pergaulan sehari-hari lewat pendekatan budaya akulturasi. Proses ini selanjutkan diwariskan oleh para ulama-ulama pesantren. Ulama pesantren ini biasanya menjadi rujukan dan tempat bertanya masyarakat, karena itu nilai-nilai syariah Islam itu terpelihara hingga kini.

Kemudian, di kalangan pedagang, kita mengenal misalnya paroan ( bagi laba), akad ini terjadi antara dua pihak. Pihak pertama adalah orang yang punya modal, dan pihak kedua adalah orang yang berdagang secara operasional di lapangan. Setelah di hitung laba bersih, maka kemudian di bagi dua; $50 \%$ untuk yang punya modal dan 50\% untuk pelaku pedagangnya. Tetapi mengenai 
proporsinya biasanya tergantung akad yang disepakati antara pemilik modal dan pedagangnya.

Sementara di kalangan masyarakat nelayan kita juga mengenal sistem bagi hasil yang polanya mirip seperti dalam dunia perdagangan. Ada akad antara pihak yang pemilik perahu dan nelayan yang mencari ikan di laut. Mereka lalu membuat kesepakatan bagi hasilnya. Proporsi keuntungan juga bervariasi, tergantung kesepakatan antar pihak-pihak yang bertransaksi (akad).

Kemudian di kalangan petani, kita mengenal banyak istilah mengenai sistem bagi hasil ini. Misalnya ada istilah pertolanan dan paroan. Pertolonan, adalah kesepakatan bagi hasil antara pihak yang punya lahan dan modal dengan pihak yang mengerjakan atau yang merawat pemeliharaan tanaman. Pihak yang punya lahan mendapatkan $2 / 3$ dari hasil panen, sementara yang pemelihara tanaman mendapatkan $1 / 3$ dari hasil panen. Sedangkan yang model paroan adalah model kesepakatan antara pemilik modal dan pemilik lahan dan setelah panen hasilnya dibagi dua secara merata.

Dalam menentukan model akad, baik di kalangan pedagang, nelayan maupun petani biasanya selalu atas bimbingan dan arahan dari kiai-kiai di pesantren. Para pedagang, petani dan nelayan biasanya rata-rata lulusan pesantren, sehingga hubungan mereka dengan pesantren terus terjalin, karena dalam melakukan berbagai transaksi selalu berkonsultasi kepada kiai atau tokoh agama yang mengerti mengenai hukum fiqih Islam. Di samping itu, pesantren sebagai lembaga pendidikan independen dan berwatak mandiri, untuk membiayai operasional pesantrennya, mereka banyak melakukan usaha-usaha, baik perdagangan, nelayan maupun pertanian. Tak sedikit juga, kiai yang juga dalam kesehariannya adalah berperan sebagai pedagang, petani dan nelayan.
Dengan kata lain, proses pribumisasi syariat Islam ini berjalan secara kultural, akulturasi dan lewat hubungan simbiosis mutualisme antara masyarakat pedagang, petani dan nelayan di satu pihak dengan kiai atau tokoh agama yang menjaga pewarisan nilai-nilai syariah Islam di tengah masyarakat. Hubungan timbal balik antara ulama dengan masyarakat inilah yang kemudian dalam bidang muamala menjadi sistem sosial bagi hasil itu.

\section{Penutup}

Terserapnya nilai-nilai Islam dalam tatanan kehidupan sosial-ekonomi masyarakat di Indonesia tidak terlepas dari strategi taktik Wali Songo dalam mengaktualisasikan ajaran Islam yang memakai pendekatan budaya akultarasi. Para ulama perintis Islam di bumi nusantara itu, sesungguhnya meniru cara dan proses dakwah Rasulullah Muhammad SAW dalam berekonomi yang kemudian dikenal dengan istilah mudharabah.

Sistem mudharabah ternyata sudah banyak dipraktekkan di Indonesia walaupun istilah yang dipakai memakai bahasa lokal seperti Jawa dan Madura. Wali Songo tidak mempersoalkan simbol, tetapi lebih mementingkan subtansi, yaitu bagaimana nilai-nilai Islam mewarnai dan terasa ke dalam kehidupan ekonomi umat.

Sistem bagi hasil yang merupakan inovasi dari ulama dalam kenyataannya telah meningkatkan kesejarahkan umat, mengurangi jumlah masyarakat miskin dan mengurangi kesenjangan yang terlalu jauh antara si kaya dan si miskin. Jadi pada intinya sistem bagi hasil ini ingin mewujudkan masyarakat yang adil dan sejahterah, berkseimbangan antara kehidupan dunia dan akhirat, antara lahir dan batin, dan antara individu dan masyarakat serta terhindar dari proses saling dzalim mendzalimi.

Al-Qur'anul Karim
DAFTAR BACAAN 
Abu al-Qasim al-Husain bin Muhammad arRaghib al-Asfahani., al-Mufradat $f i$ Gharib al-Quran., Mathba'ah Mushathafa al-Babi al-Halabi, Kairo, 1967.

Ahmad, Mustaq, Etika Bisnis dalam Islam, Penerjemah Samson Rahman, Pustaka Al-Kautsar, Jakarta, 2001, hlm. 64.

Ahmad, Ziauddin, Dr., AlQur'an:Kemiskinan dan Pemerataan Pendapatan No. 09, Dana Bhakti Prima Yasa, Yogyakarta, 1998.

Feillard, Andree, NU Vis-a-Vis Negara: Pencarian Isi, Bentuk dan Makna, LKiS, Yogyakarta, Cetakan II 2008.

Hamid al Husaini, Riwayat Kehidupan Nabi Muhammad $S A W$., Penerbit Yayasan al Hamidy, dalam Karnaen, 1996.

Haron,Sudin.,Bala Shanmugam. Islamic Banking System Concepts \& Applications. Pelanduk Publications, Malaysia, 1997.

Kahf, Monzer, Ekonomi Islam: Telaah Analitik terhadap Fungsi Sistem Ekonomi Islam, Pustaka Pelajar, Yogyakarta, 1995.

Mannan, Muhammad Abdul., Ekonomi Islam: Teori dan Praktek., Penerjemah Potan Arif Harahap., PT. Intermasa, Jakarta, 1992.

Muhammad, Teknik Perhitungan Bagi Hasil dan Profit Margin pada Bank Syariah, UII Press, Yogyakarta, 2004.
Muzadi, Hasyim., Islam Rahmatan Lil'alamin, Menuju Keadilan dan Perdamaian Dunia (Perspektif NU), Pidato Pengukuhan Doktor Honoris Causa, Surabaya, 2006.

Nababan,M.Faruq., Sistem Ekonomi Islam, Pilihan setelah Kegagalan Sistem Kapitalis dan Sosialis. UII Press, Yogjakarta, 2000.

An-Nabhani, Taqyuddin., Membangun Sistem Ekonomi Alternatif Perspektif Islam., Penerjemah Mahfur Wahid, Risalah Gusti, Surabaya,1999.

Perwataatmadja, Karnaen., Membumikan Ekonomi Islam di Indonesia. Penerbit Usaha Kami, Jakarta, 1996.

Qardhawi, Yusuf, Kiat Islam Mengentaskan Kemiskinan, Gema Insani Press, Jakarta, 1995. , Peran Nilai dan Moral dalam Perekonomian Islam, Penerjemah K.H. Didin Hafidhuddin., Robbani Press, Jakarta, 2001.

Rivai, Veithzal; Andi, Buchari., Islamic Economics, Bumi Aksara, Jakarta, 2009.

Wahid, Abdurrahman, Islam Kosmopolitan: Nilai-nilai Indonesia \& Transformasi Kebudayaan, Wahid Institute, Jakarta, 2007. 